\title{
Mineralogical Observation Made During the Kinetic Dissolution Study of Chalcopyrite Mineral in Sulphate Media under Free pH at Room Temperature
}

\author{
Kolela J Nyembwe, Elvis Fosso-Kankeu*, Frans Wanders and Edward Ntumba Malenga
}

\begin{abstract}
An attempt to determine the various phenomena at play and leaching mechanism of chalcopyrite dissolution, was conducted on a chalcopyrite concentrate. The study was performed at atmospheric conditions (room temperature) in a stirred Erlenmeyer flask with $10 \%$ solid at free $\mathrm{pH}$ in acidic sulphate system. It appears that, the mineral dissolution is to some extent dependent on the $\mathbf{p H}$. The $\mathrm{Cu}$ dissolution curve was characterized at the early stage by a rapid withdrawal of both copper and solid residue. Leachate solid residue characterization results, obtained from the $\mathrm{X}$-ray diffraction revealed the presence of intermediate minerals phases including bornite, covelite and chalcocite. Thermodynamic calculations predict that the dissolution of bornite and chalcocite would be spontaneous while covelite was found to be refractory. In addition to that, sulfur and gangue related mineral were identified as the dissolution reaction products.
\end{abstract}

Keywords: Chalcopyrite, dissolution, mechanism, mineral phases

\section{INTRODUCTION}

Approximately $70-80 \%$ of metallic copper $(\mathrm{Cu})$ is produced from the chalcopyrite mineral, the major copper sulfide mineral in nature used for copper production [1,2] and the most refractory copper sulfide towards hydrometallurgy [3]. An

Manuscript received October 03, 2018. This work was supported and sponsored by the North-West University in South Africa

Kolela J Nyembwe is with the Water Pollution Monitoring and Remediation Initiatives Research Group, School of Chemical and Minerals Engineering, Faculty of Engineering, North-West University, South Africa.

Elvis Fosso-Kankeu is with the Water Pollution Monitoring and Remediation Initiatives Research Group, School of Chemical and Minerals Engineering, Faculty of Engineering, North-West University, South Africa,

Frans Wanders is with the Water Pollution Monitoring and Remediation Initiatives Research Group, School of Chemical and Minerals Engineering, Faculty of Engineering, North-West University, South Africa,

Edward Ntumba Malenga is with the Mineral Processing and Technology Research Centre, Department of Metallurgy, School of Mining, Metallurgy and Chemical Engineering, Faculty of Engineering and the Built Environment, University of Johannesburg, estimation of $85 \%$ of the copper production worldwide is obtained via the pyrometallugical route [4]. Efforts made over the past three decades in order to promote copper extraction through the hydrometallurgical method continue to be vain due to the controversy surrounding the mechanism of the dissolution and the incomplete copper recovery [5]. This, has resulted in several leaching processes in which the ferric sulphate system possess many advantages including a simple chemistry, low capital and operation cost, environment [6-15] and it is convenient for the recovery of copper by solvent extraction and electrowining [16, 17].

The hindered dissolution and slow dissolution kinetic is believed to be caused by the formation of a passive layer, building up on the mineral surface. The nature, characters (composition) and its formation mechanism are subject to controversy [18, 19]. There are four main hypotheses explaining the structure of the impermeable passive layer. According to the first hypothesis, the elemental sulphur formed as the reaction product to prevent further diffusion of reactant to unleached chalcopyrite $[20,21]$. The second theory and the commonly cited [22] suggests the formation of the copper rich polysulfide which takes place as a result of solid state transformation through the preferential iron dissolution. This theory is referred to as the metal-deficient sulfide. The third theory holds responsible iron precipitates compounds, which act as a barrier hindering the dissolution. The candidates for this last theory include jarosite, jarosite like and goethite. These phases are usually formed due to the hydrolysis of iron [23].

To the authors knowledge most of the dissolution studies conducted on the chalcopyrite mineral focus mainly on the mechanistic, electrochemical, morphological. In these investigation the kinetic information with regards to the $\mathrm{Cu}$ dissolution were obtain from the leachate characterization after periodic withdrawal of a small solution portion. While, the residue characterization are usually assessed at the study time resolved. The purpose of this work is to present the kinetics in regards to $\mathrm{Cu}$ dissolution and simultaneously using the diffraction analysis to present the mineralogical changes taking place during the leaching of chalcopyrite. Lastly, to use thermodynamic prediction, in order to explain the dissolution and mineralogical observations. 


\section{MATERIAL AND METHOD}

\section{A. Material}

Similar concentrate sample as earlier characterized by Nyembwe et al [24] was used in this study. The sample was obtained from a local South African mining company. The chemical analysis (XRF) exposed the presence of $\mathrm{Cu}, \mathrm{Fe}$ and $\mathrm{S}$ respectively, at $36.4,26$ and $10 \%$. Calcium associated to carbonate at $15 \%$ followed by silicon at $2 \%$ were found as the major impurities. The tables below (Tables 1 and 2) present the chemical composition of the sample used in this study while Fig 1shows the mineralogical composition of the sample.

TABLE I: CHEMISTRY MAIN ELEMENTS

\begin{tabular}{|c|c|c|c|c|}
\hline \multicolumn{5}{|c|}{ Bulk Chemistry Main elements (XRF results) } \\
\hline Elements & $\mathrm{Ca}$ & $\mathrm{Fe}$ & $\mathrm{Cu}$ & $S$ \\
\hline Composition (\%) & 15.21 & 26.23 & 36.39 & 10.61 \\
\hline \multicolumn{5}{|c|}{ TABLE II: TRACE ELEMENTS } \\
\hline \multicolumn{5}{|c|}{ Bulk Chemistry trace elements (XRF results) } \\
\hline Elements & $\mathrm{Mg}$ & $\mathrm{Al}$ & $\mathrm{Si}$ & $\mathrm{Sr}$ \\
\hline Composition $(\%)$ & 4.04 & 1.01 & 4.67 & 0.23 \\
\hline
\end{tabular}

Concentrate diffraction pattern

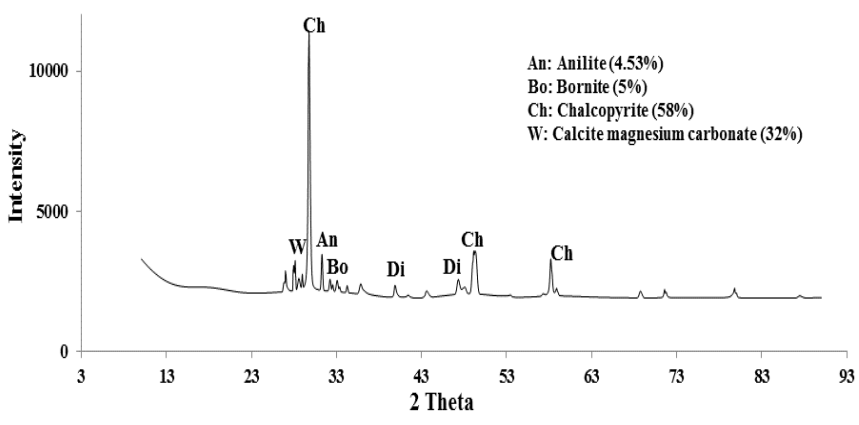

Fig 1: Sample mineralogy

\section{B. Method}

The dissolution test was performed at atmospheric pressure in a glass $\left(600 \mathrm{~cm}^{3}\right)$ reactor on continuous basis for twelve hours at room temperature. The leach slurry was magnetically stirred (6 $\mathrm{cm}$ ) at a constant speed of $200 \mathrm{rpm}$ (adjusted in order to avoid vortex creation). The experiment was conducted in sulphate system $\left(\mathrm{H}_{2} \mathrm{SO}_{4}-\mathrm{Fe}_{2}\left(\mathrm{SO}_{4}\right)_{3}\right)$. The media was prepared by mixing distilled water, sulfuric acid and ferric sulphates ( 0.05 moles) at an initial $\mathrm{pH}$ of 0.5 . A $10 \%$ solid-liquid ratio was used for the experiment.

The $\mathrm{pH}$ was free (not maintained constant), this intended to establish the nature of the dissolution reaction in regard to acid consumption. Kinetics information was obtained after collecting 10 milliliters from the dissolution vessel each 20 minutes. The leachate was filtered and analyzed for its metallic content $(\mathrm{Cu}$ and $\mathrm{Fe})$ under atomic absorption flame spectrometer (AAFS -thermo fisher). The solid residue was characterized using X-ray diffraction (XRD) for its mineralogical content.

Mineral content: The diffraction pattern associated to the mineral composition of the various samples was obtained after subjecting the sample under X-ray diffraction analysis (XRD) using the Rigaku Ultima IV with PDXL analysis software, set at $40 \mathrm{kV}$ and $30 \mathrm{~mA}$, with a detection limit of $2 \%$. This technique enables the identification of the various mineral phases and their quantification [21]. The operating condition of the diffractometer was Cu radiation $30 \mathrm{kV}$ and $25 \mathrm{~mA}$ recorded at 2 theta, varying from 5-950. The powered samples were scanned at a speed of 0.5 degrees per minute, with a width step of 0.01 degrees.

The leachate metallic content was quantified by means of Atomic Absorption Flame Spectrometer (AAFS-Thermo Scientific ICE 3000 series \&Varian 220). The equipment was alimented by air/ acetylene burning at high temperatures. The leachate samples were aspirated into the flame alimented by air/ acetylene, burning at high temperature in order to favor atomization of metallic traces.

\section{RESULTS AND DISCUSSION}

\section{A. Leachate characterization}

Figure 3 displays the dissolution curve of $\mathrm{Cu}$ from and $\mathrm{Fe}$ the chalcopyrite concentrate in acidified sulphate solution at free $\mathrm{pH}(0,5$ initial $\mathrm{pH})$. It also shows the evolution or behavior of $\mathrm{pH}$. Iron content $(\mathrm{Fe})$ as presented in the figure summarizes the dissolved $\mathrm{Fe}$ originating from the mineral, obtained after subtracting the initial Fe content (virgin leaching) solution used to prepare the leaching solution from the collected leachate $\mathrm{Fe}$ content. $(\mathrm{Fe}$ (mineral) $=\mathrm{Fe}$ (AAFS)-Fe (in leaching liquor).

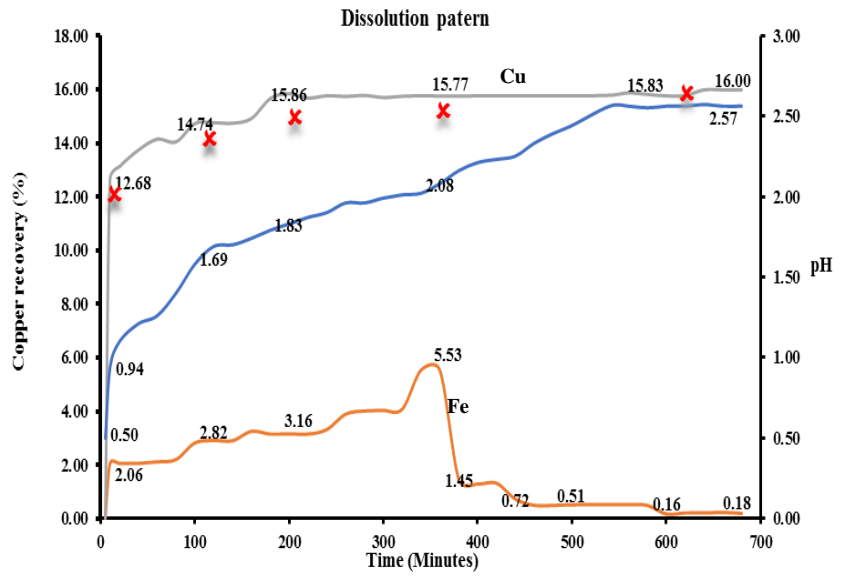

Fig 2: leachate metallic content and $\mathrm{pH}$ evolution

It was observed that the $\mathrm{Cu}$ dissolution curve obeyed to the parabolic like behavior as in previous studies [25]. Only $16 \%$ of $\mathrm{Cu}$ from the mineral was recovered in the leachate after 12 hours dissolution. The curve shows a rapid $\mathrm{Cu}$ withdrawal at the early stage of the dissolution (the first 20 minutes). This rapid stage was associated to a low $\mathrm{pH}$ value. Based on this fact, it could be said that the acid content or $\mathrm{pH}$ plays a vital role in the recovery (dissolution) of copper. Similarly, the earlier study, conducted by Aydogan et al [26], reported that the $\mathrm{Cu}$ dissolution rate increased with increasing the sulfuric acid concentration. This could probably explain the sharp $\mathrm{Cu}$ withdrawal as observed at the earlier stage of the dissolution.

The dissolution appears to be hindered at relatively high $\mathrm{pH}$ values which are accompanied with $\mathrm{Fe}$ precipitation. The 
obtained results support the earlier study suggesting that the dissolution of chalcopyrite appears to be an acidic consuming reaction [27]

\section{B. Leaching solid residue XRD characterization}

Figure 3, Tables 3 and 4 show the mineral content of the various solid residues collected according to the red dots as shown on the $\mathrm{Cu}$ dissolution curve. The progressive chalcopyrite dissolution was observed; a decrease in its major peak intensity was noticed suggesting an effective mineral dissolution [28]. In addition to that, the $\mathrm{Cu}$ dissolution appeared to be accompanied with new mineral phases formation. These new phases include bornite chalcocite and covelite. They are regarded as intermediate phase step before the complete decomposition to $\mathrm{Cu}^{2+}$ and $\mathrm{Fe}^{2+}$ [29].

Apart from the intermediate phases formed, precipitates minerals associated to the mineral matrix nature and the leaching media system was also observed to evolve. These precipitates were gypsum related to the carbonatite calcite while the iron products (hydroxide and/ or oxides) and elemental sulphur were linked to the dissolution media system. The precipitates also displayed an increase in their respective content through increasing peak intensity, and were find to progressively cumulate.

The presence of gypsum could be attributed to the carbonatite hosting ore. Calcium $(\mathrm{Ca})$ is susceptible to form sulphate compound in the presence of sulfuric acid [30].

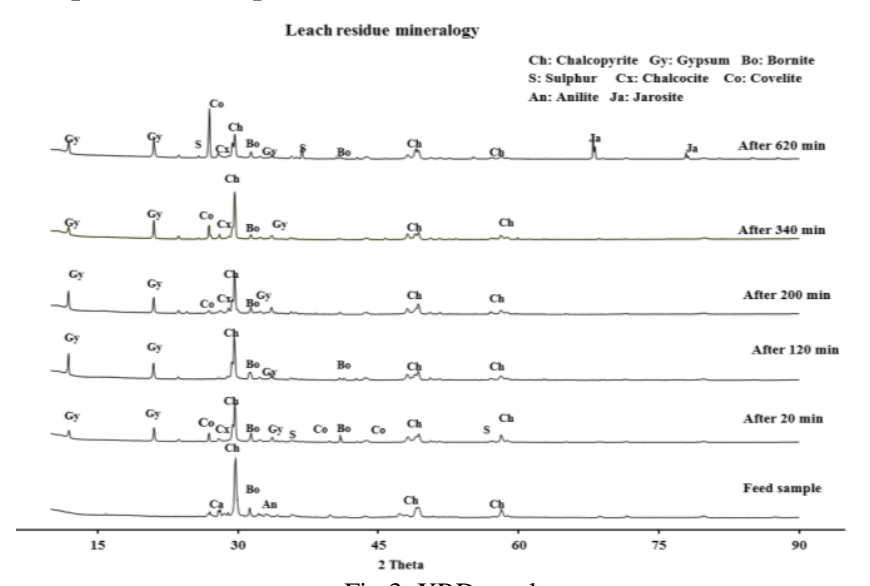

Fig 3: XRD results

TABLE III: MiNERAL PHASE'S QUANTIFICATION (CU AND FE PHASES RIR RESULTS)

\begin{tabular}{|c|c|c|c|c|c|c|c|}
\hline \multicolumn{8}{|c|}{ Bulk Chemistry Main elements (XRF results) } \\
\hline \multicolumn{5}{|c|}{ Copper phase $(\%)$} & \multicolumn{3}{|c|}{ Iron phases $(\%)$} \\
\hline & $\mathrm{Ch}$ & $\mathrm{Cx}$ & Co & Bo & $\mathrm{Wu}$ & Mag & Hem \\
\hline Feed & 58.01 & $* * *$ & $* * *$ & 5.00 & 32.0 & *** & $* * *$ \\
\hline 20 & 47.2 & 9.7 & 4.8 & 5.6 & 2.1 & 0.8 & $* * *$ \\
\hline 200 & 28.8 & 13.0 & 6.8 & 7.0 & 3.2 & 1.5 & 0.7 \\
\hline 200 & 22.7 & 12.0 & 5.8 & 5.3 & 3.5 & 2.1 & 1.9 \\
\hline 400 & 22.9 & 6.8 & 5.7 & 1.3 & 2.8 & 3.5 & 2.9 \\
\hline 620 & 20.5 & 7.8 & 4.7 & 1.5 & 3.0 & 4.6 & 3.0 \\
\hline
\end{tabular}

TABLE IV: MINERAL PHASE'S QUANTIFICATION (JAROSITE, SULPHUR AND GYPSUM RIR RESULTS)

\begin{tabular}{|c|c|c|c|}
\hline \multicolumn{4}{|c|}{ Bulk Chemistry Main elements (XRF results) } \\
\hline \multicolumn{3}{|c|}{ System phases $(\%)$} & \multirow{2}{*}{$\frac{\text { Mineral gangue }}{\text { Gy }}$} \\
\hline & $\mathrm{Ja}$ & $\mathrm{S}$ & \\
\hline Feed & $* * *$ & $* * *$ & *** \\
\hline 20 & 9.7 & 2.0 & 25.7 \\
\hline 200 & 13.1 & 3.4 & 29.1 \\
\hline 200 & 12.6 & 7.1 & 34.0 \\
\hline 400 & 14.0 & 10.6 & 30.0 \\
\hline 620 & 10.7 & 2.5 & 16.2 \\
\hline
\end{tabular}

\section{Thermodynamic consideration}

Theoretically the dissolution of chalcopyrite can be discussed on the basis of the thermodynamic stability zone as summarized on the Eh-pH (pourbaix) diagram. The Eh-pH (Pourbaix) diagram favors the oxidative dissolution of sulfide minerals [31]. The diagram predicts the predominance area of the various susceptible pieces or phase in regards to their equilibrium condition for all possible redox reactions [32].

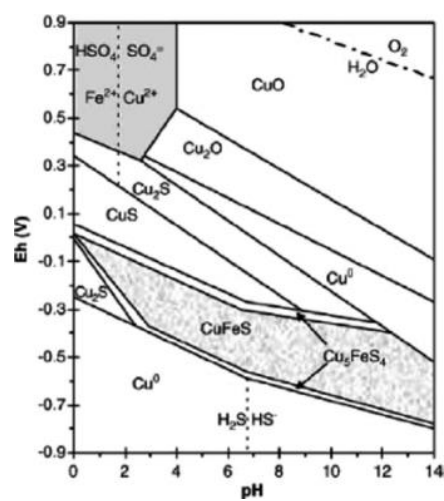

Fig 4: potential -pH diagram Cu-Fe-S- $\mathrm{H}_{2} \mathrm{O}$ at $25^{\circ} \mathrm{C}$

It could be seen that as the potential increase on the mineral surface during the dissolution, various oxidation reaction reactions could take place in acidic $\mathrm{pH}$. These reactions promote the formation of intermediates phases including: bornite, covelite, and chalcocite. The diagram also shows that, successful copper dissolution from the mineral could be achieved after increasing the redox potential above $0.44 \mathrm{~V}$ [33]. In addition to that, all intermediate formed phases are susceptible to dissolve in acidic media at potential above $0.5 \mathrm{~V}$ (SHE).

The residue XRD analysis showed the possibility to obtain chalcocite, covelite and bornite as products of the dissolution in sulphate media. Equations 1 to 3, respectively show the Gibbs energy (spontaneity) calculation for the intermediates phases' mineral formation was obtained using the HSC chemistry 5.

\subsubsection{Direct chalcopyrite mineral dissolution}

$\mathrm{CuFeS}_{2}+2 \mathrm{Fe}_{2}\left(\mathrm{SO}_{4}\right)_{3}=\mathrm{CuSO}_{4}+5 \mathrm{FeSO}_{4}+2 \mathrm{~S} \quad \Delta \mathrm{G}=-16.3(1)$ 


\subsubsection{Chalcopyrite dissolution through mineral intermediate}

phase's formation (covelite, chalcocite and bornite)

\subsubsection{Formation of copper intermediates phases}

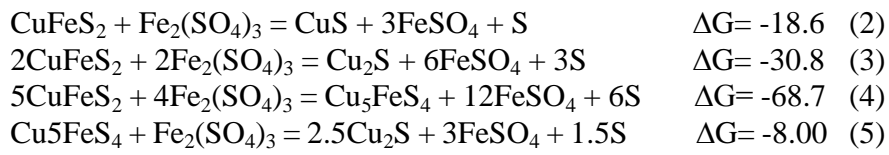

3.1.2.2 Dissolution of intermediate phases for complete copper dissolution

$\mathrm{CuS}+\mathrm{Fe}_{2}(\mathrm{SO} 4)_{3}=2 \mathrm{FeSO}_{4}+\mathrm{S}+\mathrm{CuSO}_{4}$

$\Delta \mathrm{G}=2.12 \quad(6)$

$\mathrm{Cu}_{2} \mathrm{~S}+2 \mathrm{Fe}_{2}(\mathrm{SO} 4)_{3}=4 \mathrm{FeSO}_{4}+\mathrm{S}+2 \mathrm{CuSO}_{4}$

$\Delta \mathrm{G}=-2.25 \quad(7)$

$\mathrm{Cu}_{5} \mathrm{FeS}_{4}+6 \mathrm{Fe}_{2}(\mathrm{SO} 4)_{3}=13 \mathrm{FeSO}_{4}+4 \mathrm{~S}+5 \mathrm{CuSO}_{4} \quad \Delta \mathrm{G}=-13.9$

\subsubsection{Phases formation related to gangue mineral}

$\mathrm{CaCO}_{3}+\mathrm{H}_{2} \mathrm{SO}_{4}=\mathrm{CaSO}_{4}+\mathrm{H}_{2} \mathrm{O}+\mathrm{CO}_{2} \quad \Delta \mathrm{G}=-32.1$

The thermodynamic prediction show that, even though direct mineral dissolution is possible as shown in Equation (1), mineral phases intermediate are more likely to form during the dissolution of the mineral. Spontaneous reactions were those involving mineral phases' mutations or intermediates (2 to 5). The dissolution of the intermediates phase was also feasible mainly for chalcocite and bornite (7 and 8). However, covelite (6) indicates that the reaction is not spontaneous at room temperature and could contribute to the passivation layer, hindering further copper dissolution. In addition, the formation of gypsum, as identified in the XRD and demonstrated in (9), could also contribute to the hindered dissolution. Moreover, the existence of elemental sulphur and iron precipitate (Jarosite) contribute to the passivation phenomenon.

\section{CONCLUSION}

During the dissolution of copper from chalcopyrite at room temperature in ferric sulphate, intermediates mineral phases are likely to occur. These intermediate phases include covelite, chalcocite and bornite. The thermodynamic predictions have shown that bornite was more likely to form followed by chalcocite and lastly covelite. The dissolution of the later phase was found to not be spontaneous unlike the other observed phases: bornite and chalcocite. The covelite phase was therefore likely to contribute to the passivation phenomenon. In addition to that the XRD leach residue demonstrated the presence various precipitates including elemental sulphur, iron products (goethite, jarosite) and gangue related mineral (gypsum) which could contribute to the hindered dissolution.

\section{ACKNOWLEDGMENT}

The authors are thankful to the local South African mining company who participated in this research by providing the samples, the extraction metallurgy laboratory at the University of Johannesburg for equipment utilization and the chemical engineering department at the North-West University for the support and promotion of this research are also acknowledged.

\section{REFERENCES}

[1] V. J. Martínez-Gómez,, J. C. Fuentes-Aceituno, R. Pérez-Garibay and J. C. Lee, "A phenomenological study of the electro-assisted reductive leaching of chalcopyrite," Hydrometallurgy, vol. 164, pp. 54-63, 2016. https://doi.org/10.1016/j.hydromet.2016.05.008

[2] A. Ruiz-Sánchez and G. T. Lapidus, "Study of chalcopyrite leaching from a copper concentrate with hydrogen peroxide in aqueous ethylene glycol media," Hydrometallurgy, vol. 169, pp. 192-200, 2017. https://doi.org/10.1016/j.hydromet.2017.01.014

[3] C. L. Aguirre, N. Toro, N. Carvajal, H. Watling and C. Aguire, "Leaching of chalcopyrite (CuFeS2) with an imidazolium-based ionic liquid in the presence of chloride," Minerals Engineering, vol. 99, pp. 60-66, 2016. https://doi.org/10.1016/j.mineng.2016.09.016

[4] Y. Li, N. Kawashima, J. Li, A. P. Chandra and A. R. Gerson, "A review of the structure, and fundamental mechanisms and kinetics of the leaching of chalcopyrite," Advances in Colloid and Interface Science, vol. 197-198, p. 1-32, 2013. https://doi.org/10.1016/j.jcis.2012.10.022

[5] E. M. Cordoba, J. A. Muñoz, M. L. Blázquez, F. González and A. Ballester, "Leaching of chalcopyrite with ferric ion. Part III: Effect of redox potential on the silver-catalyzed process," Hydrometallurgy, vol. 93, p. 97-105, 2008.

https://doi.org/10.1016/j.hydromet.2008.04.016

[6] E. Fosso-Kankeu, A. Mulaba-Bafubiandi, B.B. Mamba, T.G. Barnard, Assessing the effectiveness of a biological recovery of nickel from tailings dumps. Journal of Minerals Engineering. Vol. 24, pp. 470-472, 2011.

https://doi.org/10.1016/j.mineng.2010.11.007

[7] E. Fosso-Kankeu, F. Waanders, A.F. Mulaba-Bafubiandi and S. Sidu, Leachability of suspended particles in mine water and risk of water contamination. $10^{\text {th }}$ ICARD/IMWA 2015; $10^{\text {th }}$ International Conference on Acid Rock Drainage \& IMWA Annual Conference. 21-24 April 2015 Santiago-Chile. Editors: Adrian Brown, Charles Bucknam, Joanna Burgess, Manuel Carballo, Devin Castendyk, Linda Figueroa, Lisa Kirk, Virginia McLemore, James McPhee, Mike O'Kane, Robert Seal, Jacques Wiertz, David Williams, Ward Wilson, Christian Wolkersdorfer. ISBN: 978-956-9393-28-0. Chap 4. Pp 1-9. 2015.

[8] E. Fosso-Kankeu, F. Waanders, and W. Botes, Recovery of Base Metals from Mine Tailings Dumps collected in the Vicinity of Potchefstroom: Leaching assisted by Complexing Agent. $7^{\text {th }}$ International Conference on Latest Trends in Engineering and Technology (ICLTET' 2015), November 26-27, 2015 Irene, Pretoria (South Africa). Editors: E. Muzenda and T Yingthawornsuk. ISBN: 978-93-84422-58-5. 2015.

[9] E. Fosso-Kankeu, F.B. Waanders, and A.H. Munyai, Susceptibility of Metals Release from Tailings Dumps Located In the Krugersdorp Area. $7^{\text {th }}$ International Conference on Latest Trends in Engineering and Technology (ICLTET' 2015), November 26-27, 2015 Irene, Pretoria (South Africa). Editors: E. Muzenda and T Yingthawornsuk. ISBN: 978-93-84422-58-5. 2015.

[10] A.H. Munyai, E. Fosso-Kankeu, F. Waanders, Biological influence on the mobility of metals from mine tailing dump located in Krugersdorp area. International Journal of Science and Research. ISSN: 2319-7064. Vol. 5, no. 4, pp. 1396-1403, 2016.

[11] A.H. Munyai, E. Fosso-Kankeu, F. Waanders, Mobility of metals from mine tailings using different types of organic acids: Batch leaching experiment. International Journal of Science and Research. Vol. 5, pp. 520-527, 2016

[12] A.H. Munyai, E. Fosso-Kankeu, F. Waanders, Effects of organic acids on heavy metals released from mine tailings. International Conference on Advances in Science, Engineering, Technology and Natural Resources (ICASETNR-16) Nov. 24-25, 2016, Parys - South Africa. ISBN: 978-93-84468-79-8. 2016.

[13] E. Fosso-Kankeu, B. Barlow, N. Lemmer and F. Waanders, Geochemical speciation of metal ions in the leachate of tailings treated with synthetic rain water. $9^{\text {th }}$ Int'l Conference on Advances in Science, Engineering, Technology \& Waste Management (ASETWM-17). 27-28 November 2017, Parys, South Africa. Award winning paper. Editors: F. Waanders, E. Fosso-Kankeu, B. Topcuoglu, M. Plaisent, Y. Thaweesak. ISBN: 978-81-934174-6-1. Pp. 19-23. 2017.

[14] T. Moncho, I.G. Erdogan, M. Emandien, S.K.O. Ntwampe, E. Fosso-Kankeu, F. Waanders, A. Rand and B. Fourie, Prediction of metals bioavailability in the soils near mining areas in Okiep, South Africa. $9^{\text {th }}$ Int'l Conference on Advances in Science, Engineering, Technology \& Waste Management (ASETWM-17). 27-28 November 2017, Parys, South Africa. Editors: F. Waanders, E. Fosso-Kankeu, B. Topcuoglu, M. 
Plaisent, Y. Thaweesak. ISBN: 978-81-934174-6-1. Pp. 142-146. 2017.

[15] E. Fosso-Kankeu and J. Redelinghuys, Bacterial ecology of biofilms sustaining pollution by acid mine drainage near mining areas in Mpumalanga Province - South Africa. $11^{\text {th }}$ ICARD/IMWA/MWD Conference "Risk to Opportunity". 10-14 September 2018 Pretoria, South Africa. C. Wolkersdorfer, L. Sartz, A. Weber, J. Burgess, G. Tremblay.ISBN: 978-0-620-80650-3 Vol 1 (2 volumes). 2018.

[16] G. Nazari, D. G. Dixon and D. B. Dreisinger, "Enhancing the kinetics of chalcopyrite leaching in the Galvanox ${ }^{\mathrm{TM}}$ process," Hydrometallurgy, vol. 105 , p. 251-258, 2011. https://doi.org/10.1016/j.hydromet.2010.10.013

[17] C. Klauber, A. Parker, W. v. Bronswijk and H. Watling, "Sulphur speciation of leached chalcopyrite surfaces as determined by X-ray photoelectron spectroscopy," International Journal Mineral Processing, vol. 62 , p. 65-94, 2001. https://doi.org/10.1016/S0301-7516(00)00045-4

[18] A. F. Tshilombo, "Mechanism and kinetics of chalcopyrite passivation and depassivation during ferric and microbial leaching," Ph.D. dissertation, Dept. Material. Eng., British Columbia Univ., 2004.

[19] S. L. Harmer, J. E. Thomas, D. Fornasiero and A. R. Gerson, "The evolution of surface layers formed during chalcopyrite leaching," Geochimica et Cosmochimica Acta , vol. 70, p. 4392-4402, 2006. https://doi.org/10.1016/j.gca.2006.06.1555

[20] R. S. McMillan, D. J. Mac Kinnon and J. E. Dutrizac, "Anodic dissolution of n-type and p-type chalcopyrite," Journal of applied electrochemistry, vol. 12, pp. 743-757, 1982. https://doi.org/10.1007/BF00617495

[21] J. E. Dutrizac, "Elemental sulphur formation formation during ferric sulphate leaching of chalcopyrite," Can. Metall. Quart, vol. 28, no. 4, pp. 337-344, 1989. https://doi.org/10.1179/cmq.1989.28.4.337

[22] C. Klauber, "A critical review of the surface chemistry of acidic ferric sulphate dissolution of chalcopyrite with regards to hindered dissolution," Internstional journal of mineral processing, vol. 86, p. $1-17,2008$.

[23] A. Sandstrom, A. Shchukarev and J. Paul, "XPS characterisation of chalcopyrite chemically and bio-leached at high and low redox potential," Minerals Engineering, vol. 18, p. 505-515, 2005. https://doi.org/10.1016/j.mineng.2004.08.004

[24] K. J. Nyembwe, E. Fosso-Kankeu, F. Wanders and K. D. Nyembwe, "Structural, compositional and mineralogical characterisation of carbonatitic copper sulfide concentrator plant streams: Run of mine, concentrate and tailings," International Journal of Mineral, Metallurgy and material, 2018.

[25] H. Majima, "Importance of Fundamental Study in Hydrometallurgy," Metallurgival and materials transactions, vol. 26, no. B, pp. 109-1122, 1995.

[26] S. Aydogan, G. Ucar and M. Canbazoglu, "Dissolution kinetics of chalcopyrite in acidic potassium dichromate solution. Hydrometallurgy 2006; 81:45-51." Hydrometallurgy, vol. 81, p. 45-51., 2006. https://doi.org/10.1016/j.hydromet.2005.10.003

[27] S. M. Javad Koleini, V. Aghazadeh and Å. Sandström, "Acidic sulphate leaching of chalcopyrite concentrates in presence of pyrite," Minerals Engineering, vol. 24, p. 381-386, 2011 https://doi.org/10.1016/j.mineng.2010.11.008

[28] A. L. A. Santos, F. A. Arena, A. V. Benedetti and D. Bevilaqua, "Effect of redox potential on chalcopyrite dissolution imposed by addition of ferrous ions," Eclética Química Journal, vol. 42, pp. 40-50, 2017. https://doi.org/10.26850/1678-4618eqj.v42.1.2017.p40-50

[29] E. M. Córdoba, J. A. Muñoz, M. L. Blázquez, F. González and A. Ballester, "Leaching of chalcopyrite with ferric ion. Part II: Effect of redox potential," Hydrometallurgy, vol. 93, p. 88-96, 2008. https://doi.org/10.1016/j.hydromet.2008.04.016

[30] M. M. Antonijevic and G. D. Bogdanovic, "Investigation of the leaching of chalcopyritic ore in acidic solutions," Hydrometallurgy, vol. 73, p. 245-256, 2004. https://doi.org/10.1016/j.hydromet.2003.11.003

[31] D. Pugaev, M. Nicol and G. Senanayake, "THE MECHANISMS OF THE PASSIVATION OF SULFIDE MINERALS IN OXIDATIVE LEACHING PROCESSES," in The Southern African Institute of Mining and Metallurgy 6th Southern African Base Metals Conference, 2011.

[32] B. Beverskog and I. Puigdmenech, "Revised pourbaix digram for copper at 5-150 C," SKI, Stockholm, 1995.

[33] T. Havlik and M. Skrobian, "Acid leaching of chalcopyrite in the presence of ozone," Canadian Metallurgical Quarterly, vol. 29, no. 2, pp. 133-139, 1990 https://doi.org/10.1179/cmq.1990.29.2.133

[34] T. Hirato, H. Majima and Y. Awakura, "The leaching of chalcopyrite with ferric sulfate. Metall. Trans. 18B, 489-496.," Metall. Trans, vol. 18B, p. 489-496., 1987. https://doi.org/10.1007/BF02654260

[35] D. Lu, W. Wang, Y. Chang, F. Xie and K. Jiang, "Thermodynamic Analysis of Possible Chalcopyrite Dissolution Mechanism in Sulfuric Acidic Aqueous Solution," Metals, vol. 6, no. 303, pp. 1-15, 2016. https://doi.org/10.3390/met6120303 